be dirninished. Attention, too, may be directed to getting wounds in these situations into a healthy condition and closing them. Interruptions might be made to allow for dressings, but hitherto this has not been tried, as such changes would probably be at the expense of comfort and simplicity. Major M. Sinclair, R.A.M.C., has suggested that in the straight triangle splint the outer side might be made of two straight metal bars like those of the 'Thomas's arm splint and that the arm might be fixed to it in a similar manner-a plan which seems well worth trying. Another disadvantage is that there is no active extension. It would be possible to arrange for an apparatus for extension beyond the outer side of the triangle, but there is no loubt that in some cases of fracture of the humerus extension can be overdone, and when it is necessary it is best applied with the 'Thomas's splint. 'The axilla, too, is not a satisfactory place for counter extension. It may again be pointed out that severe and very septic cases, and those where secondary haemorrhage is likeiy, are best treated on a 'Thomas's splint, at any rate until the local condition lias greatly improved.

I have to thank Captain M. H. Watney, R.A.M.C., for many $x$-ray plates and for the photographs from which the illustrations are taken.

\section{THE POSITION OF THE OPERATION FOR THE EXCISION OF A CARTILAGE IN MILITARY SURGERY.}

By T. E. HAMMOND, F.R.C.S.,

SURGEON TO THE NEWPORT MILITARY HOSPITAL; LATE SURGEON

TO THE ALDER HEY MILITARY HOSPITAL.

THE average stay in hospital following an operation of the excision of a cartilage is in the case of civilians threo veeks; in four weeks the patient is again back at work. It has become increasingly evideut that the prognosis in the case of soldiers is not nearly so good. At the request of General Sir Robert Jones the stritistics of cartilage operations performed at Alder Hey Military Orthopaedic Hospital were investigated.

$$
\text { A. Conditions Present. }
$$

The total number of cases admitted with the diagnosis of iisplaced cartilage to the end of 1917 was 283 . The total number of cases operated upon for the excision of a cartilace or a syuovial fringe was 112 In many of the remaining 171 cases syovial fringe was lin rothing abnormal could be found, while in others only slight wasting of the quadriceps was observed. In 20 cases definite steo-arthritis quas present, in 7 tuberculous disease, in 4 villous synovitis, and in one sarcoma of the lower end of the femur.

B. Comparison of Cases Admitted during the Correspomining Four Months of 191:5, 1916, 191\%.

\begin{tabular}{cccccc|c|c}
\hline & & & & & & Admissions. & Operations. \\
\hline 1915 & $\ldots$ & $\ldots$ & $\ldots$ & $\ldots$ & $\ldots$ & 28 & 17 \\
1916 & $\ldots$ & $\ldots$ & $\ldots$ & $\ldots$ & $\ldots$ & 50 & 16 \\
1917 & $\ldots$ & $\ldots$ & $\ldots$ & $\ldots$ & $\ldots$ & 52 & $\mathrm{J3}$
\end{tabular}

C. Results of Operations.

Of the 112 cases operate: 1 upon 8 were discharged as fit fo general service immediately; 99 were discharged to a comman lépôt as fit for general service within four months; 5 were discharged as fit for home service only.

D. Average Stay in Hospital.

The average stay in hospital before operation was 22 days, and varied from 3 to 50 days. The average stay in hospital after operation was 85 days, and varied from 21 to 135 days.

E. Final Category of Patients Disclearged after Operation.

In order that the final category of officers and men discharge as tit for general service in four months should be kno:vn, a request was sent to Records for their posting after discharge with the present category. Replies were received in 36 cases.

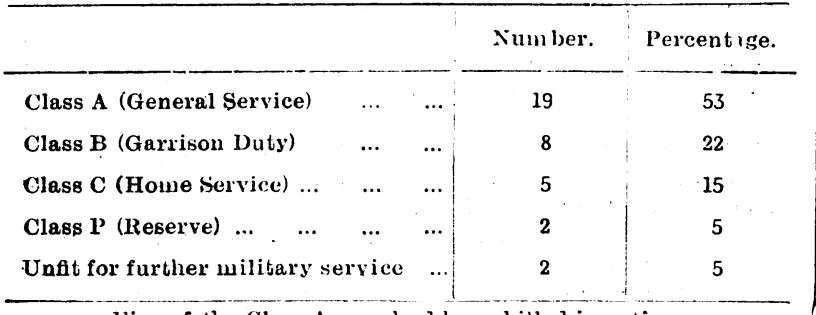

Five of the Class A men had been killed in action.
F. Final Category of Patients not Operated on.

For comparison a similar proceeding was carried out in casses in which nothing abnormal was found with the knee, and the soldier was discharged to a command dépott as fit for general service in four months. Replies were received in 27 cases.

\begin{tabular}{llllll|c|c}
\hline & & & & & & Number. & Percentage. \\
\hline Class A $\ldots$ & $\ldots$ & $\ldots$ & $\ldots$ & $\ldots$ & $\ldots$ & 9 & 33 \\
Class $1 \ldots$ & $\ldots$ & $\ldots$ & $\ldots$ & $\ldots$ & $\ldots$ & 4 & 15 \\
Class $C \ldots$ & $\ldots$ & $\ldots$ & $\ldots$ & $\ldots$ & $\ldots$ & 5 & 19 \\
Class $1 . .$. & $\ldots$ & $\ldots$ & $\ldots$ & $\ldots$ & $\ldots$ & 6 & 22 \\
Lnfit for further military service & $\ldots$ & 3 & 11 \\
\hline
\end{tabular}

Symptoms of a Displaced Cartilage.

These are briefly as follows:

Stage of Dislocation. - Sudden locking of the joint with marked pain, followed by rapid effusion and tenderness over the cartilage. With proper treatment the effusion disappears aud full movement is regained. In some cases complete recovery may follow, but there is a marked tendency for the dislocation to recur. Each recurrence is followed by less pain and a less marked tendency for effusion to arise.

Intervening Stage.-The patient may complain of weak ness and instability of the knee, especially marked when walking on rough ground. There is usually tenderness over the edge of the cartilage and wasting of the quadriceps. At the time of dislocation physical signs are well marked. The intervening stage is characterized by the complete absence of such signs in many cases, and is the stage in which the soldier usually reaches the orthopaedic hospital.

The Effects of a Displaced Cartilage on a Soldier.

When a cartilage has once been displaced, a soldier runs the greatest risk of a recurrence in the face of the enemy, since the dislocation may recur during a charge, raic or patrol. Such an accident may be disastrous to him and to his comrades. Apart from this danger coustint recurrence as a result of marching over the uneven ground at the front is only to be expected. 'This may lead to clironic synovitis and even arthritis. Therefore no soldier who has once suffered from a displaced cartilage should be returned to the firing line until this has been removed. There is not the same objection to returning such men to the A.S.C. or the Mechanical 'Transport.

\section{Internal Derangement of the Knee a Farourite} Complaint of Malingerers.

With the prolongation of the war there is a tendency for the soldier in all armies to become war weary and for malingering to develop, especially among conscripts. Simulated internal derangements of the knee are by no means uncommon, and such cases, especially in the intervening stages, are often exceedingly difficult to diagnose. The statistics given under $B$ indicate that there is a tendency for malingering in this respect to increase.

It must not be inferred that malingering in the British army is common. 'To Alder Hey practically all doubtful cases from the Western Command were sent. These numbered 283 in three years, and in only 51 cases was nothing abnormal found, a small number for such a period

Pre-operative Treatment.

In certain cases diagnosis was evident, as, for instance, when locking was still present. In the intervening stages no signs apart from tenderness over the cartilage and wasting of the quadriceps were present, and the diagnosis wis of ten difficult. Wasting of the quadriceps occur's in ail cases of internal derangement; it may also occur in a normal knee which is kept stiff and not fully nsed. Con. sequently, while the absence of wasting indicutes that there is nothing abnormal in the joint, its presence, while supporting, does not prove that some derangerent exists.

In all doubtful cases the soldier:was put through a full gymnastic course each day, following which an examination for limiter movement, effusion, ete., was made. Under no consideration was an operation perforned until some. lhing mure thau the soldier's statement was present to 
Wrerant the diagnosis. It was the nccossity for findiug detinite plyysical signs which accounts for the prolonged arerage stay in hospital bofore operation (D).

\section{Operative Treatment.}

The operative technique and post-operative treatinent introduced by General Sir Robert Jones was invariably carried out.

Post-operatice Treatment.

Complete recorery following the operation was in many crses delayed. When the soldier was anxious to rejoin his unit the average stay in hospital was one month. In other cases the soldier was anxious to prolong his stay in hospital and complained of weakness and instability of the linee, though full movement was present. In such cases wasting of the quadriceps. was the only physical sigu. A soldier with such symptoms and the added wasting of the quadriceps might obtain sympathy wher inspected by inother medical officer. Consequently no soldier was dis chiırged to a command dépót until the quadriceps liad regained its full volume and strength under massage, gymnastic exercises, and electrical treatment. Without the co-operation of the patient this was often delayed, ind nccounts for the prolonged post-operative stay in 1:ospital (D)

ilien, in spite of all treatment. wasting persisted, the patient was discharged to sedentary work; this accounts for the five cases discharged as fit for home setvice only (C).

$$
\text { Finrlher Itistory af the latimut. }
$$

The patient on joining the command dépot is of ten anxions to avoid long route marches, and now complains of pain in the scar, weakness and instability of the lince. and walks with a limp. Wasting of the guadriceps suain arises. With an unsympathetic medical olticer the soldies realizes the ganie is up, and is soon passed out Class A. Sirould the medical othicer show any sympathy the symptoms persist, and tho soldier is eventually passed out in a low category. This is especially likely to happen in the case of medical officers who believe that the excision of a cartilage prevents a soldier from agnin becoming fit for active serrice. Such judgement is not in accordance with facts, and simply encourages malingering.

'That too much attention is paid to subjective symptoms anct too little to physical signs is especially shown in the cuse of men discharged in whom nothing abnormal was mesent in the linee; only 33 per cent. of such cases were piassed fit for active service (F). In both $E$ and $F$ all the soldiers, after a short stay at the command dépôt, shonld have been discharged as fit for general service.

The Position of the Operation in Military Surgery.

From a purely inilitary aspect an operation of choice is only justifiable if it raises the soldier's category, or relieves him of a concition the persistence of which would be liarmful. It is dangerous for a soldier, liable to recurrent (iislocation, to be placed in the firing line (Class $\mathrm{A}$ ). 'The liiphest categury in which he should be put is B (garrison duty), and then only if recurence is infrequent, otherwise arthritis may arise.

Internal deraugement of the knee in the intervening stage is easily simulated. In a donbtful case the conscientious medical officer will often give the patient the benefit of the doubt, since he realizes the risk of sending the genuine case back into the firing line, and knows that subjective symptoms without definite physical signs are not uncommon. Were all such cases to be returned to the firing line a grave injustice would be done to the genuine caise. On the other hand were all the cases to be placed in Class B malingering would certainly increase.

Careful investigation of all donbtful cases is essential, and owing to the increased facilities for diagnosis most of these cases find their way to the home hospitals. It is the difficulty of proving that anything wrong is present in the knee that accounts for the prolonged pre-operative stay in liospital.

Finll movement of the knee after an operation is usually regained in three woeks, and graduated exercises should then be started. There would be no necessity for the cases to stay in huspital were it possible for them to be sent to a special command clépôt to be under the superrision of a medical officer who understands his work, and the method of developing the guadriceps by graduated and resistance excrcises. The post-overative stay in hospital would thus be considerably redaced, and a much largcer percentage of the patients would rejoin their units in inuch sliorter period of time.

'Tliat only 53 per' cent. of the men discharged are finally passed as tit for general service is due to lack of judgement and perhaps energy on the part of the medical officers at the command or regimental dépots. During my term of office as registrar at Alder. Hey on no occasion dic any communication about a knee operation arrive. That the category of 47 per cent. should have been lowered withont uny reference to the nature of the operation in. dicates that far too much attention is paid to subjectivo symptoms. With proper supervision 95 per cent. of tho cases operated upon sliould have been placed in Class $A$.

\section{A CIEAN MIIIK SUPPLY.}

13Y

SHERIDAN UELAPINE, M.B., C.MI., M.Sic.,

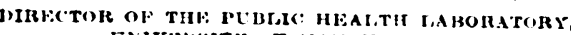

$$
\text { ENIVERSITY UF MANCHLSTEL. }
$$

Th: Sanitary Committee of the Manchester City Council las had under consideration for some years the improve. ment of the millk supply. 'The report which it recently published on the methods of testing cow's milk in relation to standards of cleanliness was prepared by tue at their request to supply them with information as to:

1. The best methor of determining the degree of contamination of milk for aclministrative purposes.

2. 'I'he actual state of the Manchester milk supply.

I may incidentally refer to the fact that the provision of a clean milk supply has been under consideration in Manchester since 1896. and that the culcestion of controlling the distribution on lines resembling those reconmended lately by the Minister of Food had received attention.

'The methods of testing cow's wilk are dealt with in the first section of the report, and in the second part the present state of the mills. smpply is shown to be very unsatisfactury. It was, for instance. found that the milk supplied to several hospitals and milk dépots wits highly contaminated, as can be seen by the following stummary :

The number of bacteria growing on ang at $37^{\circ} \mathrm{C}$. Was-Over 1,000,000 per c cm. in 39 per cent. of the simules. 100,000 to $1,000,000$ per c.cm. in 43 per cent. of the simililes

As regards the sonring time at 30 (C. it was fomm to beIess than ten hinus in 26 per cent. of the simples. Jen to fliteen hours in 55 per cent. of the shmples.

Filteen to twenty hours in 13 per cent. of the sanipies.

Il was also found that the proportion of tuberculous simples was three times as great as before the beginning of the war.

As in my opinion this deplorable state was only in smiall part clue to errors in the methods of distribution $I$ felt it wy duty to give additional information regurdius the ways in which the milk becomes contaminated, and the methors of collection and distribution which slould be adopted to protect milli ayainst pollution.

Detailed evidence is given in the report showing that the most serious sources of pollution are to be found at the farm, where dirt from the cow, the shippon, and the milkers, is allowed access to the milk at the time of milking, and where dairy vessels of various kinds may, eren when apparently clean, harbour numerous bacteria. It is also demonstrated that the straines on which the farmer depeuds for the removal of oross dirt is an important source of contamination, and that cven the cooler is not above reproach.

Of the experiments mentioned in the report the following is instructive:

Three cows were milked into sterilized covered vessels. and their milk was mixed in a sterilized churn. Part of this milk was then struined through a common strainer in uye at the time, and received in an ordinary, alparently clean, but mot sterilizerl chmn. The unstrained milk remsining in the sterilized churu, and the strained milk transferred to the ordinary clurn was carried to town by road, and examined two othinary churn was carried to tor
and a hiulf hours after milkiug.

The unstrained milk way fumd to contain 1,500 hacteria per c.cm.

The straimed milli was found to contain 43,200 bacteria ler c.cm. 